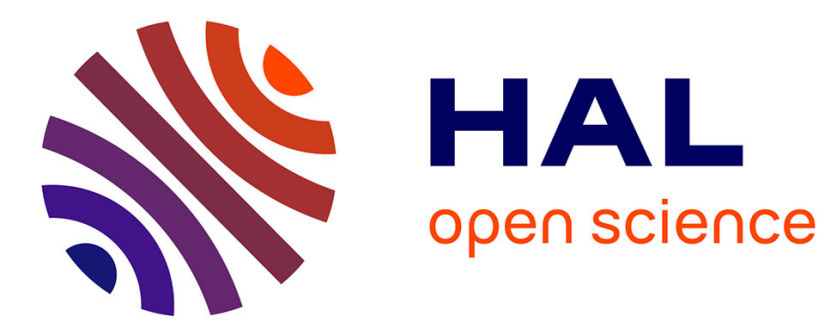

\title{
Scientific note on microsatellite DNA analyses revealing diploid and haploid drones in bumblebee mass breeding
}

\author{
Kevin Maebe, Ivan Meeus, Maarten Ganne, Felix Wäckers, Guy Smagghe
}

\section{To cite this version:}

Kevin Maebe, Ivan Meeus, Maarten Ganne, Felix Wäckers, Guy Smagghe. Scientific note on microsatellite DNA analyses revealing diploid and haploid drones in bumblebee mass breeding. Apidologie, 2014, 45 (2), pp.189-191. 10.1007/s13592-013-0237-2 . hal-01234714

\author{
HAL Id: hal-01234714 \\ https://hal.science/hal-01234714
}

Submitted on 27 Nov 2015

HAL is a multi-disciplinary open access archive for the deposit and dissemination of scientific research documents, whether they are published or not. The documents may come from teaching and research institutions in France or abroad, or from public or private research centers.
L'archive ouverte pluridisciplinaire HAL, est destinée au dépôt et à la diffusion de documents scientifiques de niveau recherche, publiés ou non, émanant des établissements d'enseignement et de recherche français ou étrangers, des laboratoires publics ou privés. 


\title{
Scientific note on microsatellite DNA analyses revealing diploid and haploid drones in bumblebee mass breeding
}

\author{
Kevin Maebe ${ }^{1}$, Ivan Meeus ${ }^{1}$, Maarten Ganne $^{1}$, Felix Wäckers ${ }^{2}$, Guy Smagghe ${ }^{1}$ \\ ${ }^{1}$ Department of Crop Protection, Faculty of Bioscience Engineering, Ghent University, Coupure links 653, 9000 Ghent, \\ Belgium \\ ${ }^{2}$ Biobest NV, Ilse Velden 18, 2260 Westerlo, Belgium
}

Received 14 June 2013 - Revised 23 July 2013 - Accepted 16 August 2013

\section{Bombus terrestris / inbreeding / microsatellite loci / commercial breeding}

Bumblebees as Bombus terrestris (L.) are used worldwide in greenhouses for the pollination of different crops such as tomatoes and sweet pepper (Velthuis and van Doorn 2006). The commercial breeding of bumblebees in 2006 was already estimated to represent a yearly turnover of $€ 55$ million, and the pollinated greenhouse tomatoes had an estimated value of $€ 12,000$ million per year (Velthuis and van Doorn 2006) and have increased since then. The breeding of bumblebees occurs in-house with strict procedures in place to exclude contact with the outside environment and to prevent inbreeding. For B. terrestris, this in-house production has been extensively optimized (Velthuis and van Doorn 2006). However, not all queens will start up typical worker-producing colonies, which switch into sexual producing colonies after the switch point (i.e., the moment that a queen switches from laying diploid workers into laying only haploid drones and/or diploid daughter queens). In a small number of colonies, the first offspring already contains drones instead of only female workers. This early production of drones, at a worker/drone sex ratio of 1:1, has already been reported in a range of haplodiploid insects. These drones are typically diploid and could be a consequence of inbreeding or homozygote alleles at the sex determination loci

Corresponding author: G. Smagghe, guy.smagghe@ugent.be

Manuscript editor: Klaus Hartfelder
(Duchateau et al. 1994; Whitehorn et al. 2009). As in bumblebees, sex is determined by the presence of complementary alleles at a single sex determination locus where heterozygotes at this locus will develop into diploid females and hemizygotes into haploid drones, while hemizygotes develop into diploid drones (Duchateau et al. 1994; Whitehorn et al. 2009).

Quality assurance (QA) within the breeding facility eliminates early drone-producing colonies; such colonies are disapproved for sales into the market. This phenomenon of early drone producing can be easily scored by sexing the first batch of offspring. We received six of those QA-failed colonies (i.e., early drone-producing colonies) from a commercial mass rearing facility in order to investigate why these colonies produced males so early. We killed and collected all the specimens of these colonies and determined the sex of each specimen under a microscope. We separated workers and drones based on the presence or absence of a sting, and the presence of male genitalia (Figure 1). Based on the frequency of drones in each colony, we divided these colonies in two groups: colonies which looks to have a biased 1:1 worker/drone ratio (group 1) and colonies which consisted of almost only drones (group 2) (Table I). Subsequently, we investigated what could be the reason for the early drone production in these colonies. Is it the typical diploid drone production with a biased sex ratio toward more drones or does the queen produces haploid drones, because the mated queens have problems to fertilize her eggs? 


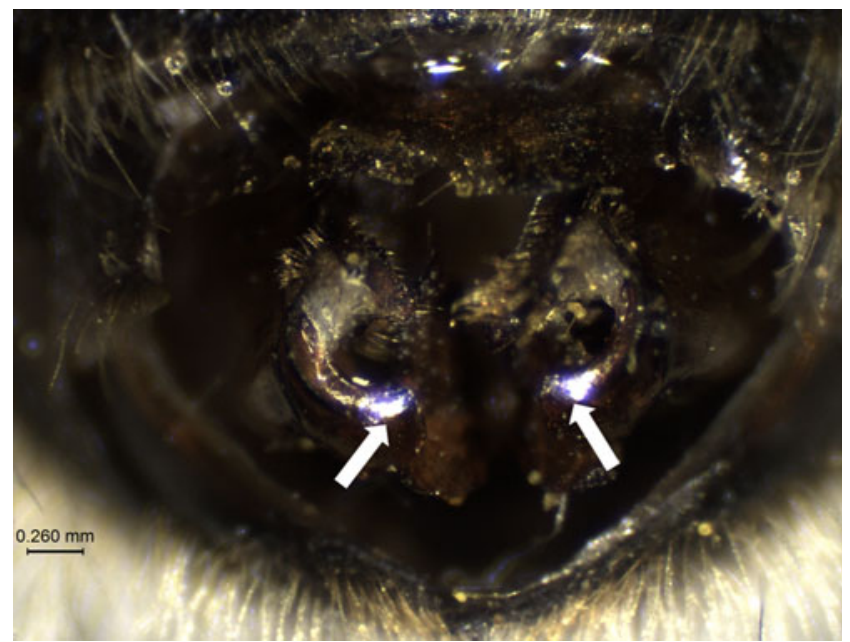

Figure 1. Micrograph of the male genitalia (white arrows) of a diploid drone used in this study

To investigate if the colonies produce diploid or haploid drones, we used microsatellites. From each colony, we genotyped the queen and five other specimens: one or two worker(s), if present, and three to four drones (Table I). Bumblebee DNA was extracted from one middle leg of each bumblebee specimen with the same method as described by Maebe et al. (2013). Workers were genotyped at ten microsatellite loci: B11, B100, B121, B126, and B132 (Estoup et al. 1993) and BT04, BT08, BT10, and BT11 (Reber Funk et al. 2006) as originally developed from B. terrestris, and BL02 (Reber Funk et al. 2006) as derived from Bombus lucorum.
Microsatellites were then amplified by PCR and visualized with capillary electrophoreses as described by Maebe et al. (2013). As shown in Table I, queens, workers, and drones were identified being diploid when they scored being heterozygous at a minimum of one loci, while bumblebees that scored homozygous for each microsatellite were scored as haploid. Based on ten microsatellite loci, the probability of scoring a true haploid drone as a haploid and not as a homozygote diploid drone is high. Even when using a high allele frequency $(f)$ in all microsatellite loci of 0.5 , the probability $(P)$ is still $99.9 \%$ with $P=\left(1-(f)^{10}\right) \times 100$.

Table I. Overview of the morphological and genetic data for each of the colonies, divided in two groups based on the sex ratio: group 1 contains three colonies with a biased worker/drone sex ratio of 2:3, while group 2 contains three colonies which consisted out of almost only drones. Data present the numbers of drones and workers within each colony, worker/drone sex ratio, presence of workers laying eggs and a queen helper, and ploidy of the drones (diploid/haploid) as determined with the microsatellite analyses in this study.

\begin{tabular}{|c|c|c|c|c|c|c|c|}
\hline \multirow[t]{2}{*}{ Group } & \multirow[t]{2}{*}{ Colony } & \multicolumn{2}{|c|}{ Numbers of } & \multirow{2}{*}{$\begin{array}{l}\text { Worker/drone } \\
\text { sex ratio }\end{array}$} & \multirow{2}{*}{$\begin{array}{l}\text { Worker laying } \\
\text { eggs }\end{array}$} & \multirow{2}{*}{$\begin{array}{l}\text { Queen } \\
\text { helper }\end{array}$} & \multirow{2}{*}{$\begin{array}{l}\text { Ploidy } \\
\text { of drones }\end{array}$} \\
\hline & & Drones & Workers & & & & \\
\hline \multirow[t]{3}{*}{1} & A & 17 & 9 & $2: 3$ & $\mathrm{~N}$ & - & Diploid \\
\hline & B & 11 & 7 & $2: 3$ & $\mathrm{~N}$ & - & Diploid \\
\hline & $\mathrm{C}$ & 9 & 5 & $2: 3$ & $\mathrm{~N}$ & Present & Diploid \\
\hline \multirow[t]{3}{*}{2} & $\mathrm{D}$ & 16 & 1 & $9: 10$ & $\mathrm{~N}$ & Present & Haploid \\
\hline & $\mathrm{E}$ & 8 & 1 & $9: 10$ & $\mathrm{Y}$ & Present & Haploid \\
\hline & F & 21 & 3 & $9: 10$ & $\mathrm{Y}$ & Present & Haploid \\
\hline
\end{tabular}


All drones produced by the three colonies belonging to group 1 were diploid and were all offspring of their founding queen (Table I). Furthermore, we tested if the sex ratios in those colonies were biased from the expected 1:1 worker/diploid male ratio. Based on a $\chi^{2}$ test (with Yates correction), the three colonies A, B, and $\mathrm{C}$ showed no significant deviation from the 1:1 sex ratio (Yates $\chi^{2}=1.885, P=0.170$; Yates $\chi^{2}=0.500, P=0.480$; and Yates $\chi^{2}=0.643, P=0.423$, respectively). However, we found a slight but significant bias from the normal 1:1 sex ratio when we pooled the data over all three colonies (Yates $\chi^{2}=3.879, P<0.05$ ). This was surprising as one might expect the opposite because diploid males have a reduced viability in comparison to workers. However, it should be remarked here that the breeding facility made the selection of the colonies based on the number of drones in the first brood. We therefore speculate that the unexpected 2:3 ratio can be explained by a sampling bias for colonies with larger numbers of drones. The colonies tested can thus be considered as typical examples of diploid drone-producing colonies explained by inbreeding or mating of nonrelated specimens with the same alleles for the sex loci (Table I).

The colonies belonging to group 2 produced only haploid drones (Table I). However, not all of these haploid drones originated from the founding queen. Some of those haploid drones were offspring produced by the queen helper, that is a bumblebee worker placed together with the queen to induce egg laying (Table I). This indicates that the queen of those colonies had problems to fertilize her eggs and could lay only unfertilized eggs which will develop to haploid drones. Furthermore, it also indicates that the queen helpers started producing haploid drones themselves, probably induced by the inferior egg laying capacity of the queen.

In conclusion, the data of this project showed that early drone-producing colonies from mass production facilities can produce diploid or haploid drones. The presence of haploid drones indicates that the queen had problems in the fertilization of her eggs, while the presence of diploid drones confirms some level of inbreeding. In addition, we remark that morphometrics and wing landmarks are interesting for future research to evaluate if they can be used for separating diploid drones from haploid ones.

\section{ACKNOWLEDGMENTS}

This study was supported by the Fund for Scientific Research Flanders (FWO-Vlaanderen). We also thank two anonymous reviewers for their helpful comments and suggestions.

Note scientifique sur des analyses d'ADN microsatellites révélant des mâles diploïdes et haploïdes dans des élevages de bourdons

Eine wissenschaftliche Notiz zur Ermittlung von diploiden und haploiden Drohnen in HummelMassenzuchten über Analysen von Mikrosatelliten-DNA

\section{REFERENCES}

Duchateau, M.J., Hishiba, H., Velthuis, H.H.W. (1994) Diploid males in the bumble bee Bombus terrestris. Entomol. Exp. Appl. 71, 263-269

Estoup, A., Solignac, M., Harry, M., Cornuet, J.-M. (1993) Characterization of (GT)n and (CT)n microsatellites in two insect species Apis mellifera and Bombus terrestris. Nucleic. Acid. Res. 21, 1427-1431

Maebe, K., Meeus, I., Maharramov, J., Grootaert, P., Michez, D., Rasmont, P., Smagghe, G. (2013) Microsatellite analysis in museum samples reveals inbreeding before the regression of Bombus veteranus. Apidologie 44, 188-197

Reber Funk, C., Schmidt-Hempel, R., Schmid-Hempel, P. (2006) Microsatellite loci for Bombus spp. Mol. Ecol. Notes 6, 83-86

Velthuis, H.H.W., van Doorn, A. (2006) A century of advances in bumblebee domestication and the economic and environmental aspects of its commercialization for pollination. Apidologie 37, 421-451

Whitehorn, P.R., Tinsley, M.C., Brown, M.J.F., Darvill, B., Goulson, D. (2009) Impacts of inbreeding on bumblebee colony fitness under field conditions. BMC Evol. Biol. 9, 152 